DOI: 10.17707/AgricultForest.61.3.19

\author{
Halil Barış ÖZEL, \\ Erol KIRDAR, Nebi BILIIR ${ }^{1}$
}

\title{
THE EFFECTS OF MAGNETIC FIELD ON GERMINATION OF THE SEEDS OF ORIENTAL BEECH (Fagus orientalis Lipsky.) AND GROWTH OF SEEDLINGS
}

\begin{abstract}
SUMMARY
In this research, the effects of magnetic field generated by Schlöder MGA 1033 magnetic field simulator model on germination percentage of the seeds of oriental beech (Fagus orientalis Lipsky.) and on the development of seedlings are investigated. In this respect, differences emerged in percentages of seeds applied with magnetic field in proportion to control group. accordingly, it has been determined that the germination percentage of the seeds that have been applied with magnetic field since $10^{\text {th }}$ week has reached much higher levels in proportion to those in control group. Accordingly, it has been found that the germination percentages of beech seeds applied with magnetic field for 15 and 20 times were much higher than the germination percentages of those located in control parcel and not exposed to magnetic field. The root length of the oriental beech seedlings emerging as a result of the germination of the seeds was investigated as a development and growth parameter. Accordingly, it has been found that the root length of the seedlings emerged as a result of the germination of the seeds exposed to magnetic field for 5 times was longer than that of seedlings in control group and other magnetic field application groups $(9.2 \mathrm{~cm})$. It has been determined that the number of seedlings emerging as a result of germination of the seeds in control parcel was much higher than the number of seedlings in magnetic field application parcels (mean $65.2 \mathrm{pcs}$ ). According to these investigations, the beech seedlings in control parcels took place in first group (mean $17.2 \mathrm{~cm}$ ).
\end{abstract}

Keywords: Oriental Beech, magnetic field, germination percentage, number of seedling, height of seedling, root length

\section{INTRODUCTION}

Being under effects of various ecological conditions, Turkey has a very rich gene sources in terms of forest asset and diversity of the forest trees. According to the researches made, the total forest asset in Turkey is 21.7 million ha, and that this area covers $27.6 \%$ of total surface of the country (Anonymous, 2014). But of this forest area, $53.3 \%$ is productive, while $46.7 \%$ is unproductive.

\footnotetext{
${ }^{1}$ Barış ÖZEL (Corresponding author: halilbarisozel@yahoo.com), Erol KIRDAR, University of Bartın, Faculty of Forestry, Department of Silviculture, 74100-Bartın, TURKEY, Nebi BILLIR, SDÜ, Faculty of Forestry, Department of Silviculture, Eastern Campus-Isparta-TURKEY

Note: The authors declare that they have no conflicts of interest. Authorship Form signed online.
} 
Inappropriate silvicultural implementations, illegal lumbering, pillage, forest fires, and especially the use of non-qualified and non-reconditioned seed materials in foresting activities have effects on these structural imperfections and productivity losses in Turkey (Ata 1995). This causes the herbal biological diversity in national forests to decrease. According to latest statistical information, there are 12,000 plant tractions in Turkey, and 2,400 of them are facing with the threat of extinction (Avc1, 2005). On the other hand, the mean annual increase in forests of Turkey is $3.7 \mathrm{~m}^{3} / \mathrm{ha}$. The same value is $5.3 \mathrm{~m}^{3} / \mathrm{ha}$ in Greece, $7.2 \mathrm{~m}^{3} / \mathrm{ha}$ in Spain, and $8.7 \mathrm{~m}^{3} /$ ha in England.

The main way of compromising this increase in Turkey's forests and the decrease in productivity is the carry out the foresting and plantation activities by using saplings obtained from qualified seeds, germination limitations of which have been eliminated. Hence, as well as the decrease in pressure on natural forest sources, the continuity of functional benefits of the forests can be ensured (Ürgenç, 1998). Having moderate and rainy climate type in general, Turkey's forests include broad-leaved species as well as needle-leaved species that show natural distribution along the forests. One of the leading species is the oriental beech (Fagus orientalis Lipsky.). With its area of distribution of 1.9 million ha, it is the species having $4^{\text {th }}$ widest natural distribution area, and it is widely used in today's many artificial regeneration and forest restoration activities. But $63.7 \%$ of oriental beech forests has ruined structure, and is waiting for being made productive again. For this purpose, within the wide geographical distribution area from Thrace to the Caspian Sea, 58 seed stands have been registered in order to collect seeds, and 38 of them are located in Turkey (Özel, 2007). Use of these seed stands located in various altitude levels are carried out according to seed transfer zoning (Atalay, 1992). The strong seeds of oriental beech generally start falling since $2^{\text {nd }}$ week of October. During natural seed fall, the moisture of the seeds is approximately $25-32 \%$. The mean seed folding temperature in natural distribution area is approximately $3 \pm 2^{\circ} \mathrm{C}$. Since beech seeds have physiologic dormancy, in order for seeds to germinate, the folding at $3 \pm 2^{\circ} \mathrm{C}$ is required. During the folding operation, the moisture content of the seed must be at maximum level (40\%). When moisture-controlled naked folding is applied, $30 \pm 2 \%$ moisture content is ideal. In order to remove the physiological dormancy in beech seeds, they should be kept within $27 \%$ moisture content for 8-10 weeks (Y1lmaz, 2010). As it can be understood from here, long period of time is required for optimal germination of beech seeds. But thanks to certain techniques developed nowadays and certain chemicals applied, the dormancy duration in species having germination limitations can be effectively decreased (Pietruszewski et al., 2007). The leading one of these techniques is the magnetic field implementation. The initial studies on the effects of magnetic field on herbal development have been carried out by. Ssawostin (1930) has determined that there has been $100 \%$ increase in heights of the wheat seedlings due to magnetic field effect (Mericle et al., 1964). In other studies, it has been reported that the productivity in species such as sunflower, cereal and soybean has been 
affected positively by magnetic field (Bosica and Zeriu, 1990; E-Ws Lian et al., 1990; Phirke et al., 1996). The effects of magnetic field implementations at various intensities on seed germination, productivity, respiration rate, temperature loss, and seedling development characteristics have been discussed in studies. In magnetic field studies on various plant species, increases in germination percentages have been detected in proportion to control groups (Gubbels, 1982). Magnetic field is also effective on root growth of the plants. In a study, it has been reported that $25 \%$ longer root growth in corn plant could be achieved by applying 5000 gauss magnetic field at the roots (Kato, 1988). Martinez et al. (2002) have utilized various magnetic fields in their study on wheat, and determined that increases occurred in heights and weights of the plants in parallel with increase in magnetic field intensity. In a study of Dardeniz and Tayyar (2007), they have determined that low-frequency electromagnetic field has positive effects on some of rooting and vegetative development parameters of Cardinal grape species (Yalçın and Tayyar, 2011).

It has been reported in many studies that magnetic field leads to various changes in different characteristics of the plants (Belyavskaya et al., 1992). Pietruszewski et al. (2007) have investigated the physiological and cytological effects of the electromagnetic field on plant development, and they have determined the positive effects of magnetic stimulation on seeds. Moreover, it has been reported that the pre-planting application of electromagnetic field may have positive effects on germination percentage, growth rate, and germination ratio, and that it can be very important for the seeds having low germination capacity. In many studies, positive effects of magnetic field on seed germination ratios have been determined (Yalçın and Tayyar, 2011; Odhiambo et al., 2009).

Being one of the essential forest trees, the seeds of oriental beech can germinate within 8-10 weeks. One of the most general effects of magnetic field implementation on the plants is the positive effect on seed germination. No study investigating the magnetic field implementation on oriental beech seed germination, growth and development could be found. Hence, in this study, it was aimed to determine the effects of magnetic field on seed germination, growth and development of oriental beech, and to research the future practical magnetic field implementation opportunities.

\section{MATERIAL AND METHODS}

The oriental beech seeds used in this study as material were obtained from Filyos State Forest Nursery. The seeds obtained from the nursery were DevrekAkçasu-originated ones, and they were collected from seed stand at $980 \mathrm{~m}$ altitude and northwestern exposure. Seeds are kept in chill store of the nursery at $-10^{\circ} \mathrm{C}$ temperature. Within the scope of the study, in order to determine the germinations in 5 different periods, a total of 1000 healthy seeds were utilized. The vital controls of the seeds were carried out via flotation and cutting experiments. 
Within the scope of this study, in order to determine the optimal intensity of magnetic field, the seeds were put into nylon bags and, at $20^{\circ} \mathrm{C}$ room temperature, were exposed to magnetic field by passing from magnetic field simulator having 4.8-5.6 mT created by Schlöder MGA 1033 in Biotechnology Laboratory of Berlin Technische Universität for 5, 10, 15 and 20 times.

The oriental beech seeds passed through magnetic field were germinated on moist filter papers within petri boxes in drying oven at $18^{\circ} \mathrm{C}$. For this purpose, each of implementations was triplicated, and 90 seeds were used in each of repetition. By observing the germination of the seeds at $2^{\text {nd }}, 6^{\text {th }}, 10^{\text {th }}, 14^{\text {th }}$ and $18^{\text {th }}$ weeks, the germination percentages were calculated and root lengths were measured in order to determine the optimal magnetic field intensity. For calculating the germination percentage, the formula below was utilized.

$$
\mathrm{GP}=\frac{\sum \mathbf{n i}}{\mathbf{N}} \times 100
$$

GP: Germination percentage $(\%)$

$n_{i}$ : the number of seeds germinated in $i^{\text {th }}$ day

$\mathrm{N}$ : the number of seeds put into germination test

In order to determine the effect of magnetic field on seedling development, the seedling heights were measured at the end of $18^{\text {th }}$ week. For this purpose, the seeds exposed to magnetic field were planted in plastic pots. For each treatment, 90 seeds were planted according to randomized blocks pattern. Then the pots were placed in cultivation rooms, where the pots were controlled in terms of temperature and light.

The statistical evaluations of the data obtained as a result of research was carried out though variance analysis according to randomized blocks experimental design. In order to determine the difference between the averages, the Duncan test was utilized.

\section{RESULTS}

In order to determine the optimal intensity of magnetic field, the germination percentage values of beech seeds were calculated. For this purpose, the beech seeds in experiment groups were exposed to magnetic field for 5,10 , 15 and 20 times. The germination percentages of beech seeds at $2^{\text {nd }}, 6^{\text {th }}, 10^{\text {th }}, 14^{\text {th }}$, and $18^{\text {th }}$ weeks, the variance analysis and Duncan test results are presented in Table 1.

As a result of variance analysis applied to mean germination percentage values transformed with Arc. Sin transformation, it has been determined that the highest germination percentage values achieved with oriental beech seeds were achieved at $18^{\text {th }}$ week $(94-98 \%)(\mathrm{P}<0.01)$ (Table 1). On the other hand, as a result of magnetic field implementation, it has been determined that the germination didn't occur at $2^{\text {nd }}$ and $6^{\text {th }}$ weeks, and that the germination percentage values of oriental beech seeds exposed to magnetic field for 15 and 20 times since $10^{\text {th }}$ week were significantly higher than other magnetic field implementations. 
Accordingly, it has been determined that the germination percentage of oriental beech seeds reached at $98 \%$ as a result of magnetic field implementations for 15 and 20 times (Table 1).

Table 1 The effects of magnetic field applied to beech seeds on germination percentages

\begin{tabular}{|c|c|c|c|c|c|}
\hline \multirow{2}{*}{$\begin{array}{c}\text { Magnetic Field } \\
\text { Implementation } \\
(\text { Times) }\end{array}$} & \multicolumn{5}{|c|}{ Germination Percentage (\%) } \\
\cline { 2 - 6 } & $2^{\text {nd }}$ Week & $6^{\text {th }}$ Week & $\begin{array}{c}10^{\text {th }} \\
\text { Week }\end{array}$ & $14^{\text {th }}$ Week & $\begin{array}{c}18^{\text {th }} \\
\text { Week }\end{array}$ \\
\hline 5 & - & - & $83^{\mathrm{b}}$ & $87^{\mathrm{b}}$ & $94^{\mathrm{b}}$ \\
\hline 10 & - & - & $85^{\mathrm{b}}$ & $92^{\mathrm{bc}}$ & $96^{\mathrm{b}}$ \\
\hline 15 & - & - & $88^{\mathrm{bc}}$ & $96^{\mathrm{c}}$ & $98^{\mathrm{c}}$ \\
\hline 20 & - & - & $92^{\mathrm{c}}$ & $98^{\mathrm{c}}$ & $98^{\mathrm{c}}$ \\
\hline \multirow{2}{*}{ Control } & - & - & $56^{\mathrm{a}}$ & $64^{\mathrm{a}}$ & $77^{\mathrm{a}}$ \\
\cline { 2 - 6 } & $C$ & $C$ & $C$ & $B$ & $A^{*}$ \\
\hline
\end{tabular}

*: The difference between the mean values presented with different letters are significant $(\mathrm{p}<0.05)$.

In this study, in order to determine the effects of magnetic field on development of beech seedlings, their root lengths were measured at the end of $18^{\text {th }}$ week. The results of variance analysis and Duncan test applied to measurement results are presented in Table 2. Moreover, the root growth values of beech seedlings as a result of magnetic field are presented in Figure 1.

Table 2. The Effects of Magnetic Field applied to Oriental Beech Seeds on root length

\begin{tabular}{|c|c|}
\hline $\begin{array}{c}\text { Magnetic Field Implementation } \\
\text { (Times) }\end{array}$ & $\mathrm{F}=56.72^{* *}$ \\
\cline { 2 - 2 } & Root Length $(\mathrm{cm})$ \\
\hline 5 & $9.2 \pm 1.5^{\mathrm{a} *}$ \\
\hline 10 & $6.8 \pm 2.1^{\mathbf{c}}$ \\
\hline 15 & $6.6 \pm 2.3^{\mathbf{c}}$ \\
\hline 20 & $5.3 \pm 2.6^{\mathrm{d}}$ \\
\hline Control & $7.2 \pm 2.4^{\mathbf{b}}$ \\
\hline
\end{tabular}

*: The difference between the mean values presented with different letters are significant $(\mathrm{p}<0.05)$.

Given the values presented in Table 2, it has been determined that there is statistically significant difference between the root lengths of oriental beech seedlings as a result of magnetic field implementations at various intensities $(\mathrm{p}<0.01)$. According to the results of Duncan test applied within this context, it has been determined that the root lengths of the seedlings germinated from beech seeds exposed to magnetic field for 5 times were much longer than control group and other magnetic field treatment groups $(9.2 \mathrm{~cm})$. 
This group is followed by beech seeds exposed to magnetic field for 10 and 15 times and the ones exposed to magnetic field for 20 times $(\mathrm{p}<0.05)$ (Table 2). According to this result, the root lengths of beech seedlings at the end of $18^{\text {th }}$ weeks don't increase with magnetic field implementation applied. Hence, it is obvious that the root lengths of the seedlings germinated from seeds in control group and the ones exposed to magnetic field for 5 times are much higher than the root lengths of the beech seedlings germinated from the seeds exposed to magnetic field for 10,15 and 20 times.

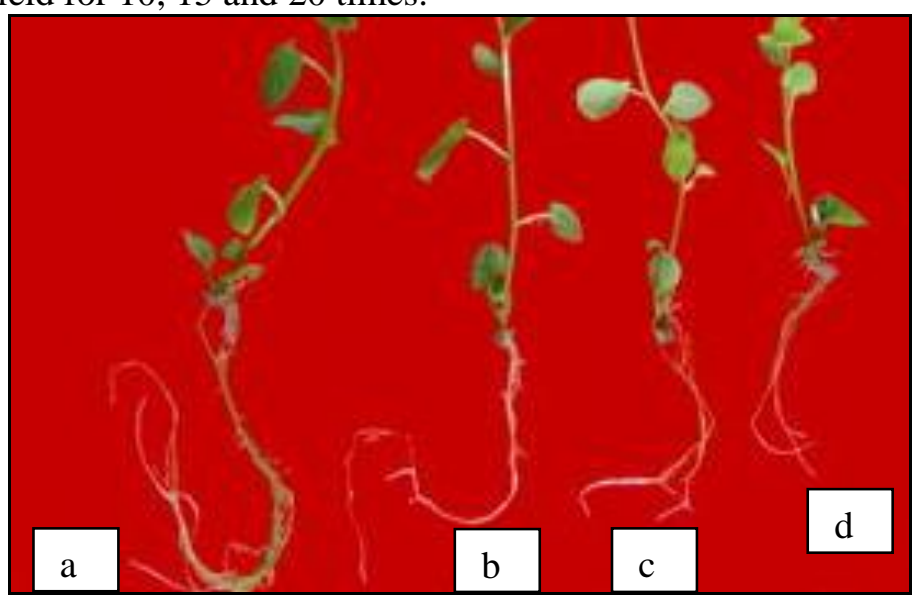

Figure 1. Root lengths of oriental beech seedlings as a result of magnetic field implementation (a: 5 times of magnetic field implementation, b: 10 times of magnetic field implementation, c: 15 times of magnetic field implementation and d: 20 times of magnetic field implementation)

In this study, the effects of magnetic field on the number and heights of the seedlings obtained from the germination of beech seeds exposed to magnetic field were also investigated. For this purpose, the number and the heights of the seedlings at the end of $18^{\text {th }}$ week were determined.

Table 3 The effects of magnetic field applied to oriental beech seeds on the number and height of seedlings

\begin{tabular}{|c|c|c|}
\hline $\begin{array}{c}\text { Magnetic Field } \\
\text { Implementation } \\
(\text { Times) }\end{array}$ & $\begin{array}{c}F=142.56^{* *} \\
\text { Number of Seedlings } \\
(\mathrm{pcs})\end{array}$ & Seedling Height $(\mathrm{cm})$ \\
\hline 5 & $48.6 \pm 1.32^{\mathrm{b}^{*}}$ & $6.4 \pm 1.23^{\mathrm{c}^{*}}$ \\
\hline 10 & $51.8 \pm 1.45^{\mathrm{b}}$ & $9.9 \pm 1.15^{\mathbf{b}}$ \\
\hline 15 & $52.5 \pm 2.24^{\mathrm{b}}$ & $11.7 \pm 1.13^{\mathrm{ab}}$ \\
\hline 20 & $60.6 \pm 2.19^{\mathrm{a}}$ & $16.8 \pm 1.09^{\mathrm{a}}$ \\
\hline Control & $65.2 \pm 2.10^{\mathrm{a}}$ & $17.2 \pm 1.03^{\mathrm{a}}$ \\
\hline
\end{tabular}

*: The difference between the mean values presented with different letters are significant $(\mathrm{p}<0.05)$. 
The results of variance analysis and Duncan test applied to counting and measurement results are presented in Table 3. In addition, the growth values of the seedlings growing from the germination of beech seeds exposed to magnetic field are presented in Figure 2.

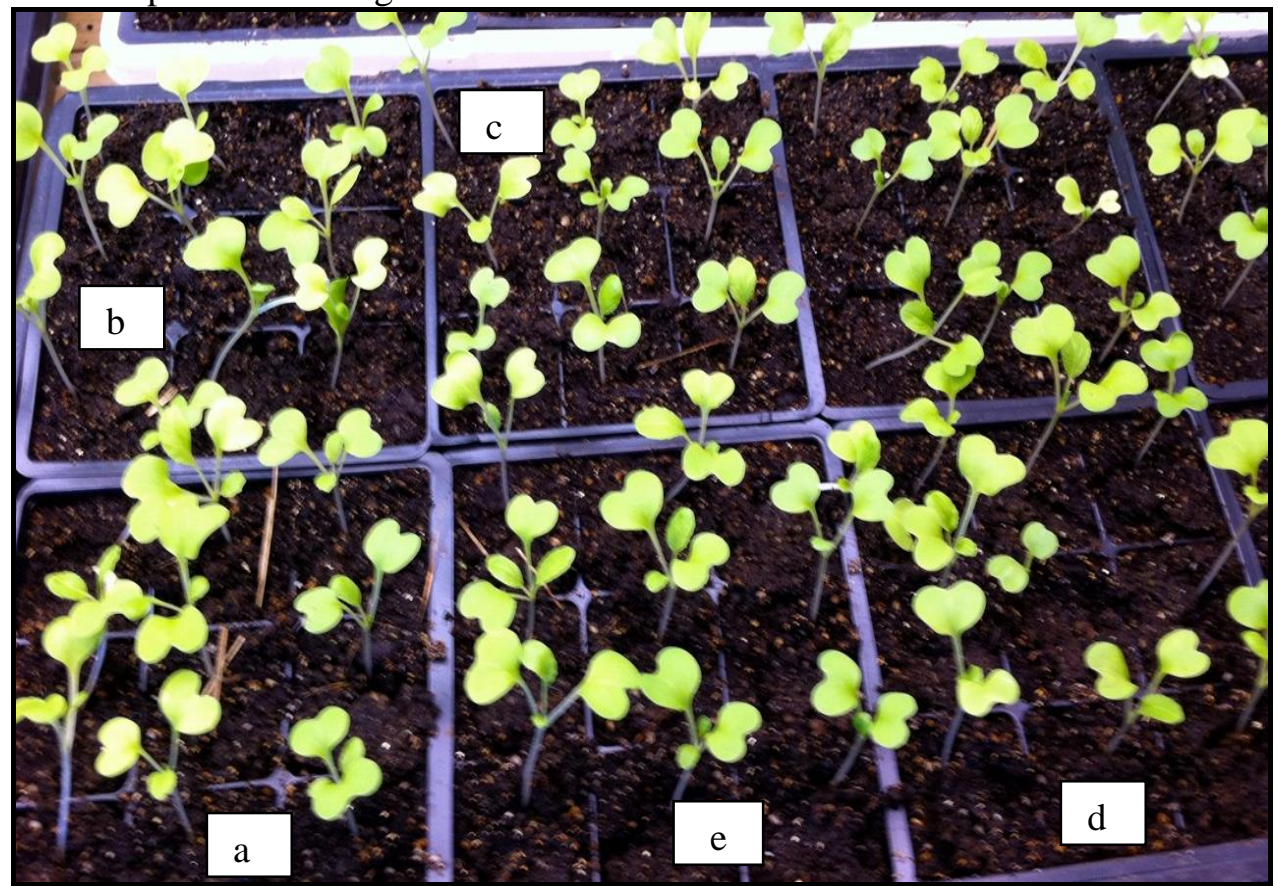

Figure 2 The number and heights of oriental beech seedlings as a result of magnetic field implementation (a: 5 times of magnetic field implementation, $\mathbf{b}$ : 10 times of magnetic field implementation, c: 15 times of magnetic field implementation, $\mathbf{d}$ : 20 times of magnetic field and e: Control).

Given the values presented in Table 3 , a statistically significant $(\mathrm{P}<0.01)$ was found between the number of oriental beech seedlings germinated from the seeds exposed to various magnetic field implementations. According to the results of Duncan test applied within this context, it has been determined that the number of beech seedlings from the beech seeds in control parcel was much higher than the seedlings from the seeds in magnetic field implementation parcels (mean 65.2 pcs). From the aspect of the number of seedlings, the control group is followed by the seedlings from the beech seeds exposed to magnetic field for 20 times $(\mathrm{P}<0.05)$ (Table 3$)$. On the other hand, the height elongation of the beech seeds at the end of $8^{\text {th }}$ week was also investigated. According to those examinations, it has been determined that there was a statistically significant difference between the control and magnetic implementation groups in terms of the number of seedlings $(\mathrm{P}<0.01)$. According to the Duncan test implemented, the beech seedlings in control parcel took place in the $1^{\text {st }}$ group in terms of seedling height (mean $17.2 \mathrm{~cm}$ ). From the aspect of seedling height, this group 
was followed by the beech seedlings germinated from beech seeds exposed to magnetic field for 20 and 15 times (Table 3). According to this result, it can be concluded that the number and height of the beech seedlings at the end of $18^{\text {th }}$ week don't increase depending on magnetic field implementation applied. Hence, it has been determined that the number and height of the seedlings in control group that have not been exposed to magnetic field were higher than the number and height of the seedlings germinated from the beech seeds exposed to magnetic field for 10, 15, and 20 times.

\section{DISCUSSION}

In this research, the effects of magnetic field on oriental beech seeds' germination, and the root and stem development were investigated. In this respect, it has been determined that there were significant differences between germination percentages of the seeds exposed to magnetic field $(\mathrm{P}<0.01)$. Accordingly, it has been found that the germination percentages of the beech seeds exposed to various number of magnetic field implementation were much higher than the germination percentages of the seeds in control parcel (Table 1). Accordingly, it has been determined that the germination percentage of the beech seeds exposed to magnetic field for 15 and 20 times were much higher than the germination percentage of the beech seeds in control parcel, where no magnetic field implementation has been implemented. On the other hand, from the aspect of germination durations of the beech seeds, it has been determined that there were significant differences between these durations $(\mathrm{P}<0.01)$, and that the highest germination percentage has been achieved at the end of $18^{\text {th }}$ week (Table 1). There is not enough number of studies on this topic. Most of the studies made are on agriculture and decoration plants. Within this context, the results obtained from this study that exposed the oriental beech seeds to magnetic field are similar with the results obtained from the studies on the seeds of Melissa officinalis L., Albizia procera Roxb. and Leucaena leucocephala Lam. (Mericle et al., 1964; Yalçın and Tayyar, 2011; Nar and Hfh, 2010). Aladjadjiyan and Ylieva (2003), in their study with magnetic field, have determined that the magnetic field led to increase in germination percentage of the seeds. Rochalska and Grabowska (2007) have revealed that changes occurred in alpha amylase, beta amylase and glutation S-transferase enzymes playing important role in germination of wheat seeds exposed to magnetic field and in satisfying the nutrition requirements of the seeds during germination. Gholami and Sharafi (2010), in their study, have applied 125-1250 mT of magnetic field on wheat seeds for various durations, and they have determined that the germination percentages of the seeds exposed to magnetic field increased in proportion to control seeds. In another study carried out with wheat, it has been determined that the magnetic field implementation increased the fresh and dried root weights, and enhanced the germination percentage (Yalçın and Tayyar, 2011). In addition, as the explanation of this topic from the physiological aspect, the magnetic field leads to certain changes in the intensities of ionic current passing through cell membrane. This interaction 
leads to osmotic pressure and the cells' capacity of water absorption. Magnetic field affects the ionic current intensity, membrane permeability, ionic concentration at both sides of the membrane, osmotic pressure, and water intake of the seeds. The increase in water intake of the seeds due to magnetic field implementation is explained with increase of the germination rate of the seeds exposed to fixed magnetic field (Yalçın and Tayyar, 2011 ).

The root lengths of the oriental beech seedlings germinated from the beech seeds exposed to magnetic field were also investigated as a development and growth parameter. Accordingly, as a result of variance analysis applied to results of root measurement, it has been determined that there was a statistically significant difference between the root lengths of oriental beech seedlings $(\mathrm{P}<0.01)$. According to the results of Duncan tests made, the root length of the seedlings germinated from the seeds exposed to magnetic field for 5 times was much longer than the root lengths of the oriental beech seedlings germinated from the seeds in control parcel and from the seeds in other magnetic field treatment groups $(9.2 \mathrm{~cm})$. This group is followed by beech seeds exposed to magnetic field for 10 and 15 times and the ones exposed to magnetic field for 20 times $(\mathrm{p}<0.05)$ (Table 2). According to this result, the root lengths of beech seedlings at the end of $18^{\text {th }}$ weeks do not increase with magnetic field implementation applied. Hence, it is obvious that the root lengths of the seedlings germinated from seeds in control group and the ones exposed to magnetic field for 5 times are much higher than the root lengths of the beech seedlings germinated from the seeds exposed to magnetic field for 10, 15 and 20 times. In a study carried out on this topic with sunflower plants, increases in root lengths were observed in 1, 3 and 9 times magnetic field implementations in 96 hours (Olcaday, 2002). In another study, it has been observed that the magnetic field implementation at low frequency had positive effects on root and leaf development in sugar beet plant (Yalçın and Tayyar, 2011).

In this study, the numbers and the heights of the seedlings germinated from the seeds exposed to magnetic fields for various times were counted and measured. In this respect, given the values presented in Table 3, it has been determined according to variance analysis applied that there were statistically significant differences between the numbers of oriental beech seedlings germinated from seeds exposed to various numbers of magnetic field $(\mathrm{P}<0.01)$. According to the results of Duncan test implemented, it has been found that the number of beech seedlings germinated from the seeds in control parcel were much higher than the number of seedlings germinated from the seeds in magnetic field treatment groups (mean $65.2 \mathrm{pcs}$ ). From the aspect of the number of seedling, the control group was followed by the beech seed group exposed to magnetic field for 20 times $(\mathrm{p}<0.05)$ (Table 3). Within this context, similar results were in studies on the seeds of Melissa officinalis L., Albizia procera Roxb. and Leucaena leucocephala Lam. (Yalçın and Tayyar, 2011).

On the other hand, also the height increase of the beech seedlings at the end of $18^{\text {th }}$ weeks was examined. It has been found that there was statistically 
significant difference between the control and magnetic field implementation groups, as well as it was in the number of seedlings $(\mathrm{p}<0.01)$. According to the result of Duncan test applied, the seedlings in control parcel took place in $1^{\text {st }}$ group in terms of seedling height (mean $17.2 \mathrm{~cm}$ ). From the aspect of seedling height, this group was followed by the beech seedlings germinated from the seeds exposed to magnetic field for 20 and 15 times (Table 3). According to this result, the number and height of the beech seedlings at the end of $18^{\text {th }}$ week don't increase depending on the magnetic field implementation applied to the seeds. Hence, it has been determined that the number and height of the seedlings in control group that have not been exposed to magnetic field were higher than the number and height of the seedlings germinated from the beech seeds exposed to magnetic field for 10, 15, and 20 times. These results obtained in the numbers and heights of the seedlings indicate that the magnetic field implementation doesn't affect the number and height of the oriental beech seedlings so much. Hence, Racuciu et al. (2007) have determined that the height of the corn plant, at $11^{\text {th }}$ day of its development, exposed to magnetic field between 50 and $250 \mathrm{mT}$ was shorter than the height of control group plant. But, despite these results achieved, it has been reported in another studies performed that the magnetic field increased the sapling height in tomatoes and sapling growth in tomatoes (Vashisth and Nagarajan, 2010). The effect of magnetic field on plant growth may arise from the effects of hormones on especially the auxin, cytokine, and gibberellin metabolism. The most important effect of the cytokines in plants is the increase in cell division, and the most important effect of auxin and gibberellins is the increase the cell elongation (Gouda and Amer, 2009). The increase in the synthesis or activity of auxin, cytokine and gibberellin in plant as a result of magnetic field implementation might lead to increase in number of leaves, area of the leaves, petiole length, tillering, and root length. In addition, in some of the studies, lower fresh and dried root weights have been determined in plants exposed to magnetic field implementation, in proportion to control groups. As the reason of this negative effect, the increase in synthesis or activity of the gibberellin and cytokine may be considered. While gibberellins have negative effects on root growth, cytokines may affect the side-root development at root tips negatively (Çelik et al., 2008). In studies carried out in order to determine the effects of magnetic field ono meristem cells of the plants, it has been determined that magnetic field is a factor affecting the normal metabolism of the cells, and it is also effective on cell reproduction in those cells. Çelik et al. (2009) have determined that the high-intensity magnetic field implementations, even if for short durations, affected the mechanisms stimulating the mitosis, and inhibited the division. Hence, as a result of the studies, it has been concluded that the low intensity magnetic field stimulates the division, while the high intensity magnetic fields inhibit it (Atak et al., 2007). In this study, as a result of shorter heights of the seedlings germinated from oriental beech seeds exposed to magnetic field than seedlings germinated from the seeds in control parcel, where no magnetic 
field has been implemented, the inhibition of mitosis division in apical meristem by increase in magnetic field intensity may be considered.

\section{CONCLUSIONS}

This study has the characteristic of being a pre-study for determining the effects of various numbers of magnetic field implementation on parameters such as germination percentage, number of seedling, root length, and seedling heights in oriental beech seeds. In this respect, this research should be enhanced and the effects of magnetic field implementation on the genetic structure of the plant should also be investigated. And by making this implementation more practical, it should be brought to the level, where it can be utilized in growing the beech seedlings to be used especially in artificial regeneration and rehabilitation activities.

\section{REFERENCES}

Anonymous, 2014. Türkiye Orman Varlığı Raporu, Orman Genel Müdürlüğü Yayınları, Yayin No:12, $73 \mathrm{p}$.

Ata, C. 1995. Silvikültür Tekniği, ZKÜ Bartın Orman Fakültesi Yayınları, Üniversite Yayın No:1, Fakülte Yayın No:2, 500p.

Avcı, M. 2005. Çeşitlilik ve Endemizm Açısından Türkiye'nin Bitki Örtüsü, İstanbul Üniversitesi Edebiyat Fakültesi Coğrafya Bölümü Coğrafya Dergisi, Sayı 13:2755 .

Aladjadjiyan A, Ylieva T. 2003. Influence of stationary magnetic field on the early stages of the development of tobacco seeds (Nicotiana tabacum L.) Journal of Central Agriculture Vol. 4(2):131-138

Atak Ç, Çelik Ö, Olgun A, Alikamanoglu S, Rzakouliev A. 2007. Effect of magnetic field on peroxidase activities of soybean tissue culture. Biotechnol. Biotechn. Equip., 21(2):166-171.

Atalay, İ. 1992. Kayın (Fagus orientalis Lipsky.) Ormanlarının Ekolojisi ve Tohum Transferi Yönünden Bölgelere Ayrılması, Orman Bakanlığı, Orman Ağaçları ve Tohumları Islah Araştırma Müdürlüğü, Yayın No: 5, Ankara, 209 s.

Belyavskaya NA, Fomicheva VM, Govorun RD, Danilov VI 1992. Structural-functional organization of the meristem cells of pea, lentil and flax roots in conditions of screening the geomagnetic field. Biophysics 37(4): 657-666.

Bosica I, Zeriu F. 1990. Effect of electromagnetic field treatment in the presence of nitrogen on cereal plant growth. Seed Abst. 013-03315.

Çelik Ö, Atak Ç, Rzakoulieva A. 2008. Stimulation of rapid regeneration by a magnetic field in Paulownia node cultures. Journal of Central Agriculture 9(2): 297-304.

Çelik Ö, Büyükuslu N, Atak Ç, Rzakoulieva A, 2009. Effects of magnetic field on activity of superoxide dismutase and catalase in Glycine max (L.) Merr. Roots, 18(2):175-182.

Dardeniz A., Tayyar Ş. 2007. Elektromanyetik alanın Cardinal üzüm çeşidi kalemlerinin vejetatif gelişimi üzerindeki etkileri. Akdeniz Üniversitesi Ziraat Fakültesi Dergisi 20(1): 23-28.

Eşitken A. 2003. Serada yetiştirilen çilekte mayetik alan uygulamasının etkileri. Atatürk Üniversitesi Ziraat Fakültesi Dergisi 34(1):25-27.

E-WS, Lian CC, Zhang JL, Shi E. 1990. Effect of magnetization on the main characters of soybean. Oil Crops in China 4:16-38. 
Gholami A., Sharafi S. 2010. Effect of magnetic field on seed germination of two wheat cultivars. World Academy of Science, Engineering and Technology 62:279-282.

Gouda O.E. and Amer G.M., 2009. Performance of crops growth under low frequency electric and magnetic fields. Proc. 6th Int. Conf. Systems, Signals and Devices, March 23-26,181-185

Gubbels GH. 1982. Seedling growth and yield response of flax, buckwheat, sunflower and pea after preseeding magnetic treatment. Can. J. Plant. Sci. 62:61-64.

Kato 1988. Effects of magnetic field on the growth of primary roots of Zea mays. Plant Cell Physiol. 29(7):1215-1219.

Martinez E, Carbonell VM, Florez M. 2002. Magnetic biostimulation of initial growth stages of wheat (Triticum aestivum L.). Electromagnetic Biology and Medicine 21(1):43-53.

Mericle RP., Mericle LW., Smith AE., Campbell WF., Montgomery DJ. 1964. Plant growth responses, 183-195 In: Biological Effects of Magnetic Field. Plenum Press, Newyork.

Nar T., Hfh K. 2010. Impact of magnetic application on the parameters related to growth of chickpea (Cicer arietinum L.). Jordan Journal of Biological Sciences. 3(4):175184.

Odhiambo JO, Ndiritu FG, Wagara IN 2009. Effects of static electromagnetic fields at 24 hours incubation on the germination of Rose Coco Beans (Phaseolus vulgaris). Romanian J. Biophys. 19(2):135-147.

Özel, HB. 2007. Bartın ve Devrek Doğu Kayını (Fagus orientalis Lipsky.) Ormanlarında Meşcere Kuruluşları ve Grup Gençleştirme Uygulamalarının Başarısını Etkileyen Faktörler, ZKÜ Fen Bilimleri Enstitüsü, Orman Mühendisliği Anabilim Dalı Doktora Tezi, $272 \mathrm{p}$.

Phirke PS, Kubde AB, Umbarkar SP 1996. The influence of magnetic field on plant growth. Seed Sci and Technol. 24:375-392

Pietruszewski S., Muszynski S., Dziwulska A. 2007. Electromagnetic fields and electromagnetic radiation as non-invasive external stimulants for seeds (Selected Methods and Responses). Int. Agrophysics 21:95-100.

Racuciu M., Creanga D., and Horga I., 2007. Plant growth under static magnetic field influence. Romanian J. Physics, 53 (1-2):331-336

Rochalska M, Grabowska K. 2007. Influence of magnetic fields on the activity of enzyems: $\gamma$ and $\beta$ amylase and glutathione S-transferase (GST) in wheat plants. Int. Agrophysics 21:185-188.

Ssawostin, P. W. 1930. Magnetic growth reaction in plants. Planta. 12: 327-77

Ürgenç, S. 1998. Ağaçlandırma Tekniği, İ.Ü Orman Fakültesi Rektörlük Yayın No:3994, Orman Fakültesi Yayın No:441, Emek Matbaacılık, 600 s.

Vashisth A. and Nagarajan S., 2010. Effect on germination and early growth characteristics in sunflower (Helianthus annuus) seeds exposed to static magnetic field. J. Plant Physiol. 167(2):149-152

Yalçın Olcaday S. 2002. Gama radyasyonuyla 1şınlanmış ayçiçeği çeşitlerinin üzerine manyetik alanın etkisi (Doktora tezi), İ.Ü Fen Bilimleri Enstitüsü, 270 p.

Yalçın S, Tayyar Ş. 2011. Oğulotu tohumlarının çimlenmesi ve fide gelişimi üzerine manyetik alanın etkisi. YYÜ TAR. BİL. DER. 21(3):190-197

Yılmaz, M. 2010. Başlıca Tohum Fizyolojisi Niteliklerinin Sıcaklık-Tohum Nemi Diyagramında Gösterimi (Doğu Kayını Tohumu Örneği), III. Ulusal Karadeniz Ormanc1lık Kongresi, Cilt II:741-745. 